\title{
Our Most Important Knowledge
}

\author{
J. T. Trevors • M. H. Saier Jr.
}

Received: 10 February 2008 / Accepted: 10 February 2008 / Published online: 8 May 2008

(C) Springer Science + Business Media B.V. 2008

Teaching and research at any level in the educational system is challenging. If we are fortunate, we continue to learn throughout our lives and contribute positively to humanity. The body of knowledge and information currently available is immense, and no one can master more than a small portion of it. The question therefore arises: what of our knowledge is the most important? Consequently, at the end of a student's formal educational training period, one might wish to ask the following question. What is the most significant or important thing you know? The answers students offer are very diverse. For many people the answer is related to their beliefs in a supernatural entity, a God, eternal life and spiritual salvation. If we ask them to reconsider their answers without including the supernatural or a religious belief system, what do you suppose their answers would be?

Some answers that Biology students have provided are as follows:

1. All life is interconnected.

2. The cell is the basic unit of life.

J. T. Trevors $(\bowtie)$

Department of Environmental Biology,

University of Guelph,

Guelph, Ontario, Canada N1G 2W1

e-mail: jtrevors@uoguelph.ca

M. H. Saier Jr.

Biological Sciences, University of California, La Jolla,

San Diego, CA 92093-0116, USA

e-mail:msaier@ucsd.edu
3. The genetic code is universal.

4. Evolution gave rise to all living organisms.

5. Human population growth is our most significant problem.

6. Poverty and wars must be eliminated.

7. We must implement universal birth control.

8. I can save lives and ease pain and suffering as a medical professional.

9. Antibiotics save lives.

10. The human genome has been sequenced.

11. Hundred of other genomes have been sequenced.

12. Global climate change could destroy our biosphere.

13. My spouse/partner loves me.

14. I know some law.

15. I can write computer algorithms that are useful.

16. We understand some aspects of matter and energy transformations.

17. I know how to make money.

18. I am an engineer and I know how to design and build things.

19. We know the speed of light.

20. The earth is not flat.

21. I know the best stocks to invest in.

22. I know nothing of real importance.

What would your own answer be? This may be a difficult question to answer, but it is an important one. After all, "An unexamined life is not worth living."

Each person has different kinds of knowledge, and no two people know or believe the same things. Some of this knowledge is likely to be of immense value and significance while some is probably of minimal value. 
This suggestion substantiates the belief that the advancement of social humanity requires contributions from people with diverse knowledge and skills. Many points of views are required, for example, to evolve functional, effective democracies and move humanity forward towards a world where everyone has basic human civil rights.

We will require first, collective knowledge, second, imagination, third, problem-solving skills, and fourth, correct action in order to rescue our common, shared biosphere from excessive human population growth and deleterious global change. While solving these challenges, we suggest that modern democratic systems of governments will best serve the good of humanity. Violence, war, super-capitalism, and unsustainable economic growth, damage our supportive planet. Our knowledge must be used to eliminate poverty and hunger, prevent discrimination and reduce the human population, initially, at least, through the free availability of universal birth control. The ultimate goal is sustainability with retention of a reasonable quality of life.

Factual information often depends on a level of enlightened scholarships. Conviction, by contrast, may depend on a religious belief system. How effectively an individual uses his or her rational mind is of prime importance to rational solution of our major problems.
Since we have posed the question of our most important knowledge, it is only fair that we attempt to answer it. Humans have the capacity to logically tackle the immense problems that confronts us. We recognize that the most critical problems we face concern the destruction of our environmental support system. A destructive progression of events will result from (1) our excessive human population, and (2) unsustainable resource consumption accompanied by pollution. These are the two facets of our environmental crisis. Yet we recognize that the means to solve these two problems are already available. Humans have excellent imaginative skills that can be used to solve problems. This is something that we think is of immense significance. And the longer we wait before providing lasting solutions, the greater the futility of our attempts will be. Inaction will lead to suffering of humans and other constituents in our biosphere to a degree never before known. We know that we can implement solutions leading to sustainability - we have the means at hand. We must overcome ignorance, irrationality and immorality so as to create lasting societies based on logic, reason, and justice. The achievement of any other goal is insufficient. The alternative is suffering, conflict, and extinction. 